\author{
Olga Natkho \\ PhD in Philology, Associate Professor \\ Federal State Budgetary Educational Institution \\ of Higher Education "Pyatigorsk State University" \\ (Pyatigorsk, Russia) \\ e-mail: onatkho@mail.ru
}

\title{
BUSINESS DISCOURSE AND ITS ROLE AS AN OBJECT OF BUSINESS AND COMMERCIAL LINGUISTICS
}

\begin{abstract}
The article deals with the notions business, professional and commercial discourse. Business discourse is a verbal or written communication between people interested in business interaction to promote their interests. It is a universal type of institutional discourse which has cultural and communicative orientation, pragma-semantic load and stylistic regulation, strict regulation and conventionality, stereotype and repeatability of communicative situations, speech etiquette. We believe that professional discourse is a vocational-oriented vocabulary, and institutional discourse is a set of social and communicative practices which brings together representatives from diverse professional communities interacting within a social institution. Commercial discourse is an embodiment of an invariant discourse model in a communicative situation in business created by a specific group of people in business. The author argues that business and professional discourses are largely synonymous while business discourse and commercial discourse are not because they are in hypo-hyperonymic relationship where commercial discourse is incorporated in business discourse.
\end{abstract}

Key words: business discourse, commercial discourse, communication

\section{О. И. Натхо}

Кандидат филолологических наук, доцент

Федеральное государственное бюджетное образовательное учреждение высшего образования «Пятигорский государственный университет» (ФГБОУ ВО «ПГУ»)

(Пятигорск, Россия)

e-mail: onatkho@mail.ru

\section{ДЕЛОВОЙ ДИСКУРС И ЕГО РОЛЬ ОБЬЕКТА ДЕЛОВОЙ И БИЗНЕС - ЛИНГВИСТИКИ}

Аннотация. В статье рассматриваются понятия делового, профессионального и бизнесдискурсов. Деловой дискурс является устным или письменным общением между людьми, заинтересованными в деловом взаимодействии с целью дальнейшего продвижения своих интересов. Это универсальный тип институционального дискурса, который обладает четко очерченной культурологической и коммуникативной направленностью, характерной прагма-смысловой нагрузкой и стилистической регламентированностью, жесткой регламентированностью и конвенциональностью, стереотипностью и повторяемостью коммуникативных ситуаций, речевым этикетом. Мы полагаем, что профессиональный дискурс является профессионально-ориентированным лексиконом, а институциональный дискурс является совокупностью социально-коммуникативных практик, который объединяет 
представителей разнообразных профессиональных сообществ, взаимодействующих в рамках какого-либо одного социального института. Бизнес - дискурс представляет собой воплощение инвариантной модели дискурса в определенной коммуникативной ситуации в бизнесе, создаваемой конкретной группой людей. Авторы приходят к выводу о том, что деловой и профессиональный дискурс в значительной степени представляют собой синонимичные явления, в то время как бизнес-дискурс и деловой дискурс нельзя отождествлять, поскольку они связаны сугубо гипо-гиперонимическими отношениями, где бизнесдискурс инкорпорирован в деловой дискурс, который является более глобальным и универсальным.

Ключевые слова: деловой дискурс, бизнес - дискурс, коммуникаџия

\section{INTRODUCTION}

At the present stage of the world community development such an aspect of interaction as business communication is one of the most popular categories of the social information exchange. Communication as such is an organized and managed information exchange, regulated according to certain rules, norms and stereotypes. Consequently, the control over messaging regulation within any kind of communication is not a mere formality but a necessity and one of the cornerstones of this type of activity.

\section{LITERATURE REVIEW}

It must be noted that business communication can be understood as any kind of communication between partners, aimed at solving certain business issues and having an interpersonal character (Imametdinova 1996). At the same time, some researchers define business communication as the process of transferring business-relevant information as a kind of communication core (Serova and Raskopina 2011). N. Fomina combines this component with a simultaneous process of communicative interaction (Fomina 2005).

Speaking of business communication studies in foreign linguistics it is important to note the limitations of professional interests by the framework of applied linguistics traditionally present among western researchers, first of all by linguomethodology and language pedagogy. Such popular research areas like Applied Linguistics in Language Acquisition, Language for Specific Purposes - LSP, English for Specific Purposes - ESP, English for Special Business Purposes ESBP, Business English can serve as a proof of this.

Also, much attention is paid to the verbal design of specific speech registers (presentations, negotiations, business and commercial correspondence, etc.); to the functioning of oral and written communication modes within specific commercial structures (workplace discourse; language at work analysis), intercultural negotiation studies, business communication process and product; intercultural business communication; corpus analysis of professional discourse; business communication education in cross-cultural contexts; media richness theory; to the development of new traditions of rhetorical science applied to business communication (Daft and Lengel 1984; Lewis 1999; Yates and Orlikowski 2002; Coupland 2005; Gillaerts and Gotti 2005; Bargiela-Chiappini et. al., 2007; Bargiela-Chiappini 2009) etc. Foreign linguists' effective work in the modern business communication study is reflected in successful functioning of the 
Association for Business Communication - ABC as well as in quarterly editions of "The Journal for Business Communication" and "Business Communication Quarterly".

In the course of this research, we tend to stick to E. Morozova's views who defined business communication as an effective and most appropriate way to organize and optimize professional, industrial, scientific, commercial, political and other activities (Morozova, 2008). This definition seems to us the most suitable for the objectives of the study to be fulfilled, because such an understanding of business communication is most closely related to the concept of business discourse as the main tool of the verbal vocational performance implementation.

\section{FINDINGS}

The subject matter of this work dictates the need to define clearly the coordinate system where we will conduct further research of the study object. Thus, the terms "business discourse" (BD), "professional discourse" (PD) and "commercial discourse" (CD) will be form-building for the conceptual-categorical apparatus used by us.

Everybody knows that modern linguistic literature presents a diverse number of "discourse" definitions. We adhere to the discourse interpretation from the standpoint of the cognitive-communicative approach, according to which it is an integral phenomenon, a cognitivecommunicative activity, the totality of the process and the result which includes both linguistic proper and extralinguistic aspects (Fairclough 1989).

F. Bargiela-Chiappini and C. Nickerson's definition has the most generalized character: in their opinion, BD is a verbal or written communication between people who are directly interested in business interaction in order to promote their interests (or their organization's interests) further, while the communicators are the owners of specific status-role relationships (Bargiela - Chiappini and Nickerson 2002).

According to S. Shilova, the phenomenon of BD should be studied as one of the types of official interaction which has its own specifics both in content and goals of communication, and in a certain nature of relations between the participants of communication (Shilova 1998). In A. Stebletsova's opinion, BD is a universal type of institutional discourse which provides the necessary level of communicative interaction in any area of professional activity (Stebletsova, 2014).

These definitions provide a visual representation of unequivocal domination of statusrole (institutional) characteristics of BD as well as about its so important quality as universality.

We find T. Shiryaeva's point of view quite interesting: she, above all, understands by BD a human purposeful verbal-minded status and role activity; and business relationships which are aimed at making a profit and based on rules and regulations accepted in business community's communication, are their common feature (Shiryaeva 2014).

Thus, BD is such a format of communication between individuals in which business relationships act as a common parameter; they are based on a common perception and understanding of the business picture of the world, a combination of professional values and knowledge, the most important principles of speech etiquette.

The comparison of the concepts of BD and business communication in some scientists' research also opens up new perspectives for a more detailed study of the issue. For example, V. Ponomarenko places special emphasis on a combination of communicative, cultural and prag- 
matic competences, which the participants of BD must have to carry out an adequate process of interaction in business and commercial area (Ponomarenko 2007).

Thus, we can conclude that along with its "institutional universality", the purposefulness of speech behavior and correlation of the business picture of the world as a basic parameter of interaction between communicators, BD has a clearly defined cultural and communicative orientation as well as the characteristic pragma-semantic load and stylistic regulation.

Examining BD with a social stratification perspective researchers position this phenomenon as a process of people's communicative interaction built according to a strict hierarchical principle which shows the cumulative illocutionary aim of BD: profit making through joint activities (Kutyaeva 2007).

So, another specific property of BD appears - its social stratification aspect expressed in creating social and cultural business communication in accordance with a hierarchy principle, causing further application of phatic, incentive and, to some extent, emotive functions of this interaction.

One of the most important specific parameters of BD, in general, and English-speaking $\mathrm{BD}$, in particular, there is a strict regulation and conventionality of the communicative norm expressed in the need to form interaction according to quite a few strict rules and limitations of speech behavior, the standardization of communication participants' verbal behavior and their subordination to fixed restrictions and rules as well as the parties' clear and consistent structuring interactions (Khramchenko 2014).

Here is an example of Partnership Agreement including the clauses on the withdrawal of capital and additional capital:

\section{Withdrawal of Capital}

No Partner will withdraw any portion of their Capital Contribution without the express written consent of the remaining Partners.

\section{Additional Capital}

Capital Contributions may be amended from time to time, according to the requirements of the Partnership provided that the interests of the Partners are not affected, except with the unanimous consent of the Partners. No Partner will be required to make Additional Capital Contributions. Whenever additional capital is determined to be required and an individual Partner is unwilling or unable to meet the additional contribution requirements within a reasonable period, as required by Partnership business obligations, remaining Partners may contribute in proportion to their existing Capital Contributions to resolve the amount in default. In such case the allocation of profits or losses among all the Partners will be adjusted to reflect the aggregate change in Capital Contributions by the Partners.

(https://www.lawdepot.com/)

As we can see, the limitations on the choice of verbal means, tough ritualization of certain genre varieties, a clear sequence of both speech actions and action components, as well as their correlation with pragmatic and socio-cultural conventions determine another characteristic parameter of $\mathrm{BD}$ - speech etiquette, which we understand as common speech acts used by the speaker in favor of the addressee according to communication participants' status-role and interpersonal relations, communicative purpose and other pragmatic factors. The most vivid and obvious example of the mandatory observance of speech etiquette in business communication is the following business call: 
ASSISTANT: Hello, Harris \& Co, how can I help you?

CLIENT: Hi, Michael Horgan here from Baylis in Miami. Is Mari Jeangeorges there?

ASSISTANT: I beg your pardon? Who would you like to speak to?

CLIENT: Mari Jeangeorges? Is she there?

ASSISTANT: Who's calling, please?

CLIENT: Michael Horgan.

ASSISTANT: I'm sorry; Mrs Jeangeorges has already left the office today. Shall I ask her to call you tomorrow?

CLIENT: No, it's okay. I'll send her an email.

ASSISTANT: Oh, okay. That'll be fine. Do you have her address?

CLIENT: Yeah, no problem. I'll email her. Bye for now.

ASSISTANT: Bye.

(Englishfor Business Communication, 2003)

The above parameters provide predictability and communicants' simulated behavior in BD. These parameters increase the automatism of speech activity reproduction through the use of generally accepted speech standards, thus making the understanding and generation of speech easier.

So, strict regulation and conventionality determine another parameter of $\mathrm{BD}$ - the aspect of stereotype and repeatability of communicative situations expressed in the use of specific expressions and standards, cliché formulas and phrases enshrined in business ethics. As an example, we give a bank employee's response letter on customer's request on Granting a Loan:

Mr. Richard Cliff

Homemakers Ltd

54-59 Riverside

Cardiff CF11JW

Dear Mr. Cliff

With reference to our meeting on 23 September, I am pleased to tell you that the credit for $£ 18,000$ which you requested has been approved.

We discussed an overdraft, but agreed it would be better if the credit were given in the form of a loan at the current rate of interest (-\%), calculated on half-yearly balances.

The loan must be repaid by 30 June 20 -, and we will hold the $£ 8,000$ ordinary shares and $£ 3,000$ local government bonds you pledged as security. We agreed that the other $£ 2000$ would be guaranteed by Mr Y. Morgan, your business associate. I would appreciate it if you could ask him to sign the enclosed guarantor's form, and if you could sign the attached agreement.

The money will be credited to your current account and will be available from 30 September subject to your returning both forms by that time.

I wish you success with the expansion of your business and look forward to hearing from you.

Yours sincerely

Ian Evans

Manager

$\underline{E n c}$

(Oxford Handbook of Commercial Correspondence, 2003) 
The given letter provides a complete picture of the classical structure of Englishlanguage business correspondence the main characteristics of which are strict regulation (clear architectonics of a business letter), the codification of a message through stereotyped forms (with reference to ..., I am pleased to tell you that...), mandatory speech etiquette regardless of the pragmatic message setting (Dear ..., Yours sincerely, ...look forward to hearing from you), an extensive use of terminology (overdraft, current rate of interest, ordinary shares, guarantor's form).

The distinctive characteristics of $\mathrm{BD}$ presented by us summarize, to some extent, and complement, to a significant degree, the relevant features of BD institutionalization identified and described by T. Shiryaeva, among which the most significant constitutive features are as follows:

a specific purpose of communication;

specific participants;

a specific social chronotop;

specific values;

specific strategies;

a specific overall picture of the world;

specific characteristics of texts (Shiryaeva 2014).

Thus, all researchers recognize BD unanimously as a multidimensional, complex phenomenon and institutional (status-oriented) composition, within its framework, communication participants are not just individuals, but representatives of a particular social institution (Karasik 2000). BD being a multifaceted cultural-cognitive-communicative and subject-cognitive, professionally-oriented sphere, is a certain theoretical abstraction, and for its adequate functioning the very concept of stratification is undoubtedly important, but not vital. This raises a logical question: how do institutional, professional and business discourses relate precisely?

To distinguish between the institutional and professional types of discourses S. Sarangi and C. Roberts put forward the daily use of actual concepts of "professional" and "institution" as their main distinguishing feature. A professional being a specialist and a member of a particular professional community, possesses specific knowledge, skills and abilities; as for the organization or any institution, they are associated with consistency, norms, the need to exercise authority more than with any group of people. From this, the scientists conclude that the professional discourse is created by professionals themselves who have clearly defined rights and obligations, and the institutional discourse combines different genre varieties authorized by a particular organization or institution. At the same time, the researchers admit the possibility of intersection of these types of discourse within one context (Sarangi and Roberts 1999).

The institutional (status, ritualized) type of discourse is presented as opposing to the personal discourse (domestic, personal). Those types of discourse that are characterized by institutionalism, function and are meaningfully used as social institutions under the same name in each relevant professional area. Any institutional professional discursive type is divided into discursive genres of a more specific nature. We assume that the most extensive is the meaningful scope of the "institutional discourse" concept which includes the concept of "professional discourse".

Within this study, the "national" point of view regarding the differentiation in question seems to be more constructive. We believe that professional discourse is a vocational-oriented vocabulary and subject area of the language which allows differentiating medical, sports, legal 
and other discourses clearly. In turn, institutional discourse is a set of social and communicative practices which are in most cases trivial; it brings together representatives from diverse professional communities interacting within any one social institution.

The next logical question is to identify the status of BD itself in the system described above.

If we examine BD restrictedly, extending its substantive and informative spaces only to the business and commercial sphere, this discourse will undoubtedly be a part of professional discourse. This approach identifies the concepts of institutional and professional discourses with "discourse in work-related settings" or "workplace interaction" (Atkinson and Drew 1979, Drew and Heritage 1992, Candlin 2002, Holmes 2006, Stubbe et al. 2003).

If understanding BD acquires more extended boundaries and includes emphasizing its interaction, intentionality and effectiveness, BD is a component of institutional discourse in this case.

We see the description of the just presented approaches to understanding the nature of BD related to its place in the "discursive hierarchy" as necessary for an adequate perception of $\mathrm{BD}$ and $\mathrm{CD}$, because the first approach narrows down the notion of $\mathrm{BD}$ to $\mathrm{CD}$ as a mechanism for mentality and ideology verbalization of commercial sphere; and under the second approach BD loses such restrictions being used in completely different social and professional institutions and thereby acquiring an autonomous and meta-discursive character at the same time. This given differential component of the discourse types shows clearly that understanding the essence of $\mathrm{BD}$ is impossible without identifying the nature of the relationship of PD and BD precisely.

The definition of the "business situation" concept supports the idea of the identification of BD with PD. This concept underlies both types of discourse and is regarded as a unit of professional communication expressed in common circumstances and relationships that occur in professional-related interactions (Koltunova 2005, Khahaleva 2012). The lack of specification regarding the type of professional activity used in $\mathrm{BD}$, emphasizes its universal nature and brings it closer to PD traditionally defined as a type of discourse that is reproduced by experts in certain professional areas to achieve the desired result (Kong 2014). In other words, the concepts of BD and PD are synonymous and in most cases interchangeable.

Speaking about the specifics of the business component itself and its verbalization inside $\mathrm{BD}$, we consider the introduction of the term "commercial discourse" to be absolutely justified and on a larger scale - to justify the need to introduce the concept of "commercial linguistics" as a new synergistic direction of applied linguistics.

In order to form a more correct idea of commercial communication and commercial discourse we consider it appropriate to examine the very concept of "commerce". This is an initiative economic activity carried out with borrowed or own funds at one's own risk and under one's own responsibility which sets as its main objective to develop one's own business or enterprise and make a profit (Borisov 2003).

Commerce can be found in every socio-economic structure. Doing business involves the production of some goods or services, financing them, trade, provision of cash loans, investments, insurance, etc. The remaining types of business are commerce, that is, product sales and various services - accounting, distribution, after-sales service and maintenance. Therefore, a business is an activity aimed at the production and sale of goods and services (Ghadessy 1988).

In the definitions mentioned above the main emphasis is on understanding business as an activity, interaction process, communication mode. However, it is worth paying attention to 
what is meant by commercial linguistics as a new direction in the development of business communication.

Y. Danyushina offers the following definition of commercial linguistics: this is a field of science that studies the language functioning and various language resources application in commercial activities and examines the components of linguistic commercial communication (Danyushina 2010).

It is easy to imagine that the object of this discipline is CD which can be defined as the verbalization of business communication used in the form of an open set of texts. For example:

The bail-out will inevitably force change. Capital controls may slow deposit flight, but after the threats of taxes, levies and now the conversion of large deposits into equity, foreign (especially Russian) money will very likely go elsewhere. Worse, the crash will shrink the economy. Fiona Mullen of Sapienta Economics, a local consultancy, notes that in 1974, when Turkey invaded the north after a Greek-Cypriot Government tried to unite with Greece, GDP fell by $17 \%$ in that year and by $19 \%$ in 1975. Although the IMF talks optimistically of a fall of only $10 \%$ this time, she predicts falls of $15 \%$ this year and another $5 \%$ in 2014. this will have horrific effects. After the collapse of Laiki, unemployment is heading for $17 \%$ this year, says Ms Mullen; it could exceed $25 \%$ in 2014

(The Economist, 2013)

The text presented above is a kind of analytical commentary on the economic situation in the world. Its regulation and partial conventionality, the use of a large amount of statistical data allow us to attribute this example to CD.

Another confirmation of an indissoluble connection of BD and CD is the fact that $\mathrm{CD}$ is a concrete embodiment of an invariant discourse model in a certain communicative situation in business which is created by a specific group of people related to business somehow, and the texts expressed in the form of different business discourse genres will be a concrete implementation of these people's activities in business situations. In this case, the CD distinctive feature in relation to $\mathrm{BD}$ will be the narrowing of the subjects range and the limitation of such communication goals. It follows that CD is a verbalization of business mentality within which thematically correlated texts are successfully combined on business topics and their entire extralinguistic context.

Based on all of the above, we conclude that business and professional discourse are largely synonymous (business discourse remains a special case of professional discourse), while business discourse and commercial discourse, whatever the case, should not be identified because they are connected by a purely hypo-hyperonymic relationship in which commercial discourse is incorporated in business discourse which is more global and universal.

Taking into account the fact that the society links inextricably the notion of culture with such phenomena as taught behaviors, social heritage, social behavior standardization, we will inevitably have to come to the conclusion that mentality is one of the determining factors which influence the formation and subsequent development of any language sphere.

Due to the proximity of mentality to the components of the philosophical definition, as well as direct correlation with linguistic science, we consider mentality as a category that, on the one hand, reflects the internal organization and, on the other hand, the differentiation of the way of seeing the world; mentality to some extent is the constitution of the national mind and soul, psycho-lingual-intellect of each different-scale linguocultural community taken separately. The mentality is very close to the concept of worldview including the conceptualization and for- 
mation of the way of seeing the world through the prism of categorizing and shaping the native language.

Therefore, despite the presence of a significant number of common parameters, every single linguoculture possessing the uniqueness of its national consciousness, owns a certain proportion of exceptional and rare features which are necessary for communication and, in particular, for business and commercial communication. Subject to the existence of a large number of "national" characteristics, a clearly defined specificity is inherent in business discourse of any linguoculture, where each communication participant creates his or her speech behavior according to the content of his or her individual cognitive system which is formed on the basis of the cognitive space of his or her native linguoculture.

\section{CONCLUSION}

Given the dominant nature of the English language which is not only the generally accepted basis of linguistic policy in a huge number of corporations and companies in the world, but also the long-established lingua franca of the modern world community, we see appropriate to study business English discourse and one of its important components - commercial discourse proper - the way how they are used by the example of the English language. We can give the following reasons as significant extralinguistic characteristics that determine this choice:

-English is a working language in about $85 \%$ of international organizations, it is given priority in the Internet, it holds powerful positions in the media, advertising, education, tourism;

-English affects other languages in the world due to its international status, and how they are used in business;

-the position of the English language proper is enhanced by other national languages due to modern globalization processes in business;

-because of its global spread, which the internationalization process in business and commercial communities, the increasing number of international business and commercial contacts contribute to, English is an essential tool for intercultural communication.

Characteristic features of the functional space in English business discourse, the set of targets and typical strategic patterns of verbal behavior between parties regulate and largely determine the conventional and regulated focus of modern BD.

However, it is worth noting the fact that at this stage of development and functioning of English-speaking business communication, there is a number of notable trends related to the general deconventionization of business and commercial communication, as well as to freer introduction of language means and methods into discourse which were previously considered indistinctive (at the level of both oral and written modes).

That is why modern business and commercial linguistics have a burning question associated with the evolutionary orientation of English-speaking BD towards the deregulation of its pragma semantic functional parameters and reduction of conventionality.

Given the emerging vector of research in the field of English BD, noticeable changes in the nature of its functioning associated with the weakening of regulated restrictions, as well as a complex of pragma semantic, linguistic and architectural parameters, we may talk about the urgent need for careful study of this linguistic-cognitive institutional phenomenon. 


\section{REFERENCES}

Atkinson, J.M., \& Drew, P. (1979). Order in Court: The Organisation of Verbal Interaction in Judicial Settings. London: Macmillan.

Bargiela-Chiappini, F. (2009). The Handbook of Business Discourse. Edinburgh University Press.

Bargiela-Chiappini, F., \& Nickerson, C. (2002). Business discourse: Old debates, new horizons. International Review of Applied Linguistics in Language Teaching, 40, 4, 273-286.

Bargiela-Chiappini, F., Nickerson, C., \& Planken, B. (2007). Business Discourse. Basingstoke, Hampshire; New York: Palgrave Macmillan.

Borisov, A.B. (2003). Bol'shoj ekonomicheskij slovar' [Big Economic Dictionary]. Moskva: Knizhnyj mir.

Candlin, C.N. (2002). Indroduction. Research and Practice in Professional Discourse. Hong Kong: City University of Hong Kong Press, 1-39.

Coupland, C. (2005). Corporate Social responsibility as Argument on the Web. Journal of Business Ethics, 62, 355-366.

Daft, R.L., \& Lengel, R.H. (1984). Information richness: A new approach to managerial behvior and organizational design. Research in Organizational Behavior, 6, 191-233.

Danyushina, Yu.V. (2010). Biznes-lingvistika - novoe sinergeticheskoe napravlenie prikladnoj lingvistiki [Commercial linguistics is a new synergistic direction of applied linguistics]. Vestnik LGU im. A.S. Pushkina, (2). URL: http://www.cyberleninka.ru/article/n/biznes-lingvistikanovoe-sinergeticheskoe-napravlenie-prikladnoy-lingvistiki (15.11.2015).

Drew, P., \& Heritage, J. (eds.) (1992). Talk at Work: Interaction in Institutional Settings. Cambridge: Cambridge University Press.

Fairclough, N. (1989). Language and Power. London, New York: Longman.

Fomina, N.V. (2005). Lingvokul'turnaya obuslovlennost' nominacii yazykovyh edinic v sfere neformal'nogo delovogo obshcheniya [The linguocultural nomination conditionality of the language units in informal business communication]: dis. ... kand. filol. nauk. Omsk.

Ghadessy, M. (1988). Registers of Written English: Situational Factors and Linguistic Features. London: Pinter Publishers.

Gillaerts, P., \& Gotti, M. (2005). Genre Variation in Business Letters. Bern: Peter Lang.

Holmes, J. (2006). Gendered Talk at Work. Oxford: Blackwell.

Imametdinova, R.H. (1996). Delovaya kommunikaciya v promyshlennom [Business communication in industry]. Gornyj informacionno-analiticheskij byulleten' (nauchno-tekhnicheskij zhurnal), (2), 74-75.

Karasik, V.I. (2000). O tipah diskursa. Yazykovaya lichnost': institucional'nyj i personal'nyj diskurs [On the types of discourse. Linguistic identity: institutional and personal discourse]. Volgograd: Peremena, 5-20.

Khahaleva, A.Yu. (2012). Diskursivnye harakteristiki situacii delovogo obshcheniya v kontekste globalizacii [Discursive characteristics of a business communication situation in the globalization context]. Vestnik Moskovskogo gos. lingv. un-ta, (14), 148-162.

Khramchenko, D.S. (2014). Funkcional'no-pragmaticheskaya evolyuciya anglijskogo delovogo diskursa [Functional and pragmatic evolution of the English business discourse]: dis. ... d-ra filol. nauk. Moskva: MGIMO.

Koltunova, M.V. (2005). Delovoe obshchenie: Norma. Ritorika. Etiket [Business communication: Norm. Rhetoric. Etiquette]. Moskva: Logos.

Kong, K. (2014). Professional discourse. Cambridge University Press.

Kutyaeva, O.M. (2007). Opyt lingvisticheskogo issledovaniya kontekstov deontieskoj modal'nosti $\mathrm{v}$ anglijskom delovom diskurse [The experience of contexts linguistic research of the deontic modality in the English business discourse]: avtoref. dis. ... kand. filol. nauk. Irkutsk. Lewis, R.D. (1999). Delovye kul'tury v mezhdunarodnom biznese. Ot stolknoveniya k vzaimoponimaniyu [When Cultures Collide: Managing Successfully Across Cultures]. Moskva: 
Delo.

Louhiala-Salminen, L. (1997). Investigating the Genre of a Business Fax: A Finish Case Study. Journal of Business Communication, 34 (3), 316-333.

Morozova, E.A. (2008). Aktual'nye aspekty issledovaniya delovyh kommunikacij v sisteme gosudarstvennoj sluzhby [Actual aspects of the business communications study in the public service system]. Srednerusskij vestnik obshchestvennyh nauk, (1), 10-20.

Ponomarenko, V.A. (2007). Frazeologicheskie edinicy v delovom diskurse (na materiale anglijskogo i russkogo yazykov) [Phraseological units in the business discourse (on the material of the English and Russian languages)]: avtoref. dis. ... kand. filol. nauk. Krasnodar.

Sarangi, S., \& Roberts, C. (1999). Talk, work and institutional order: Discourse in medical, mediational and management settings. Berlin: Mouton de Gruyter.

Serova, T.S., Raskopina, L.P. (2011). Delovaya mezhkul'turnaya kommunikaciya v professional'noj deyatel'nosti specialist [Business intercultural communication in the expert's professional activities]. Vestnik Permskogo nacional'nogo issledovatel'skogo politekhnicheskogo un-ta: Problemy yazykoznaniya i pedagogiki, (5), 16-25.

Shilova, S.V. (1998). Soblyudenie i narushenie principov rechevogo obshcheniya v delovoj kommunikacii [Compliance and violation of speech communication principles in business communication]: avtoref. dis. ... kand. filol. nauk. Sankt-Peterburg.

Shiryaeva, T.A. (2014). Strukturno-soderzhatel'naya i funkcional'naya paradigma sovremennogo delovogo diskursa [Structural, content and functional paradigm of modern business discourse]: dis. ... d-ra filol. nauk. Pyatigorsk.

Stebletsova, A.O. (2014). K voprosu o tipologii delovogo diskursa. Novye tendencii v obrazovanii i nauke: opyt mezhdisciplinarnyh issledovanij [On the issue of the business discourse typology. New trends in education and science: the experience of interdisciplinary research]. Rostov-na-Donu, 659-662.

Stubbe, M. [et al.]. (2003). Multiple discourse analyses of a workplace interaction. Discourse Studies / Victoria University of Wellington. London, Thousand Oaks, CA and New Delhi: SAGE Publications, 5 (3), 351-389.

Yates, J., \& Orlikowski, W. (2002). Genre systems: Structuring interaction through communicative norms. Journal of Business Communication, 39 (1), 13-35.

Information about the author: Olga Natkho - PhD in Philology, associate professor of the Chair of Profession-Oriented English Language. Federal State Budgetary Educational Institution of Higher Education "Pyatigorsk State University" (Russia)

e-mail:onatkho@mail.ru

Сведения об авторе: Ольга Игоревна Натхо - доцент кафедры профессиональноориенти-рованного английского языка федерального государственного бюджетного образовательного учреждения высшего образования «Пятигорский государственный университет» (ФГБОУ ВО «ПГУ») (Россия)

e-mail: onatkho@mail.ru

Manuscript received: $12 / 20 / 2018$

Accepted for publication: $01 / 25 / 2019$

Рукопись получена: 12/20/2018

Принята к печати: 01/25/2019 